Saudi Journal of Medical and Pharmaceutical Sciences

Abbreviated Key Title: Saudi J Med Pharm Sci ISSN 2413-4929 (Print) |ISSN 2413-4910 (Online) Scholars Middle East Publishers, Dubai, United Arab Emirates Journal homepage: https://saudijournals.com/sjmps

Original Research Article

\title{
Pharmacognostical \& TLC Fingerprinting of Andrographis Paniculata (Kalmegh)
}

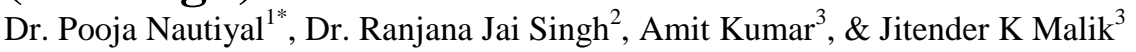 \\ ${ }^{1}$ Smt. Manjira Devi Ayurvedic Medical College and Hospital, Dhanari, Uttarkashi, India \\ ${ }^{2}$ Om Ayurvedic Medical College Hospital and Research Center, Badheri Rajputan, Uttarakhand 249405, India \\ ${ }^{3}$ Smt. Manjira Shikshan and Prashikshan Institute Hitanu Dhanari, Uttarkashi, India
}

\author{
DOI: $\underline{10.36348 / \text { sjmps.2020.v06i02.003 }}$ | Received: 27.01.2020 | Accepted: 03.02.2020 | Published: 08.02 .2020 \\ *Corresponding author: Dr. Pooja Nautiyal
}

\section{Abstract}

Kalamegha (Andrographis paniculata) is a medicinal plant conventionally used for the treatment of anti-inflammatory, antioxidant, antibacterial, antiparasitic, antispasmodic, antidiabatic, anti carcinogenic, Hepatoprotective ,antipyretic, antidiarrhoeal, nematocidal, anti-HIV and numerous infectious diseases ranging from malaria to dysentery. The plant is extensively used in ayurvedic and homeopathic systems of medicines. The drugs are said to be lord of all plants, as it conquers number of diseases. In Samhita and Chikitsa grantha, Kiratatikta and Kalamegha drugs are very frequently indicated in diseases like Daah, Kasa, Jawaragan, Swans, Udar. In the present work an attempt has been made to emphasize the folk herbal medicine which will aid in the identification of fresh as well as dried crude sample of leaves anatomically and Pharmacognostical. The study deals with macroscopic, microscopic, phytochemical analysis and TLC fingerprinting. These studied will provide referentially information for correct identification and for standardization.

Keywords: Kalamegha (Andrographis paniculata), Microscopy, Phytochemical investigations \& TLC profiling.

Copyright @ 2020: This is an open-access article distributed under the terms of the Creative Commons Attribution license which permits unrestricted use, distribution, and reproduction in any medium for non-commercial use (NonCommercial, or CC-BY-NC) provided the original author and source are credited.

\section{INTRODUCTION}

Herbal drugs play a significant role in health care programs particularly in developing countries. Ancient Indian literature incorporates a remarkably broad definition of medicinal plants to be potential sources of medicinal substances [1]. Andrographis paniculata (Kalamegh) is an herbaceous plant in the family Acanthaceae, local to India and Sri Lanka. The plant is famous in northeastern India as Maha-tita means "king of bitters". As an Ayurveda herb it is known as Kalmegh or Kalamegha, meaning "dark cloud". It is also known as Bhui-neem, meaning "neem of the ground", since the plant, though being a small annual herb, has a similar strong bitter taste as that of the large Neem tree (Azadirachta indica) [2]. It has been used for past era in Asia to treat GI tract and upper respiratory infections, fever, herpes, sore throat, and a variety of other chronic and infectious diseases. As per Indian Pharmacopoeia it is a chief constituent of at least 26 Ayurvedic formulations [3].

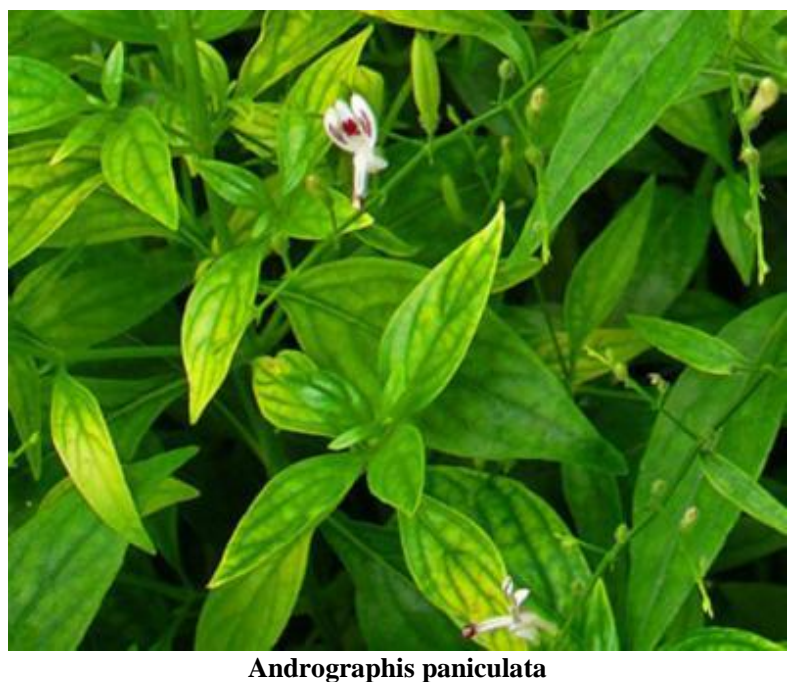

Andrographis paniculata 


\begin{tabular}{|l|l|l|}
\multicolumn{4}{|c|}{ Various Ayurvedic properties of action and Pharmacological properties of Kalmegh [4, 5] } \\
\hline Ayurvedic properties & Therapeautic Usage & Pharmacological properties \\
\hline Rasa : Tikta & Arsh, Attisar, Jwar, Kandu, & Antiinflammatory,Antioxidant, \\
Guna : Laghu,Ruksa & Kaamla, Kustha, Parmeha, Varn, & Antidiabetic,Antileshmanial, \\
Vipaka : Katu & Yakritvikar, Twakvikara. & Anti-diahoeal and intestinal effects, Antivenom \\
Virya : Sheeta & & \\
Karma : Deepan, Jwaragna, & \\
Krimigan. Anti-HIV assay \& Antifertility activity. \\
Pachhana.Kalpha- pittahara. \\
\hline
\end{tabular}

\section{Materials ANd Methods \\ Collection}

The sample of Kalamegha was collected from Haridwar, State - Uttrakhand. The sample of Kalmegh was collected by scholar under the guidance of Supervisor after identifying the source of plant as per standard description.

\section{Date of Collection}

(Haridwar).

$$
\text { Andographis }
$$

panniculata-10/08/2017

\section{Authentication}

The plant was authentication was done Botanical Survey of India (BSI), Dehradun. Acc.No: 118083

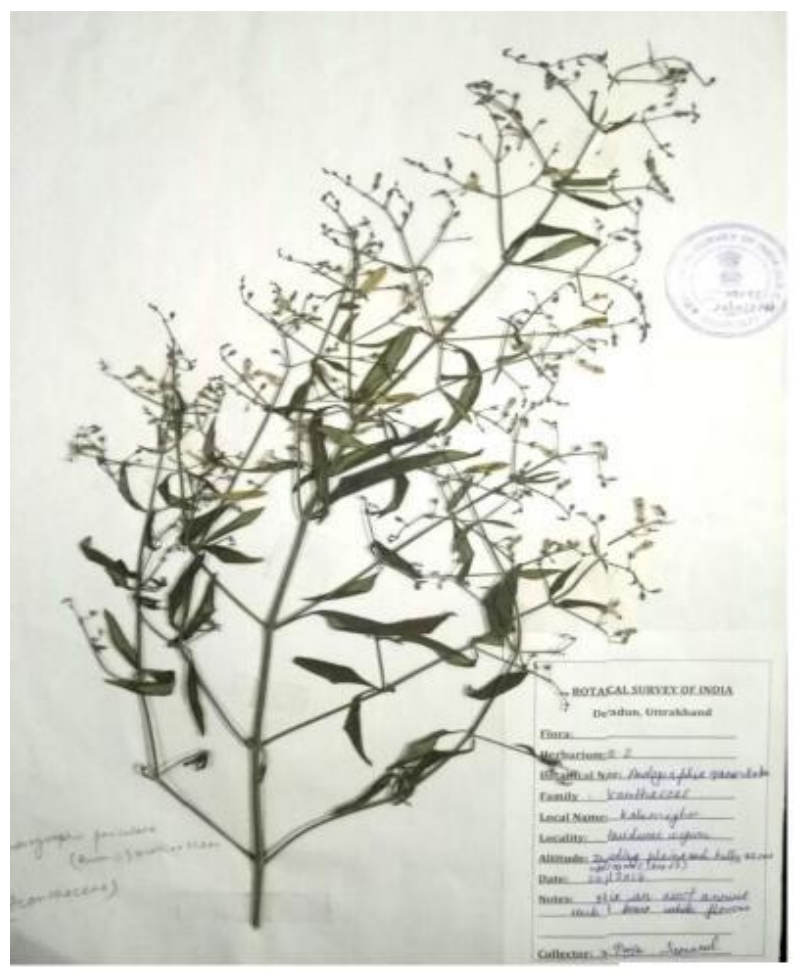

\section{Specimen of Andographis panniculata}

\section{Microscopic Study}

Microscopic study of crude drugs is another aid of Pharmacognosy which can be helpful in the process of standardization of medicinal plants. This study can be helpful in identifying genuine drug by their known histological characters through Transverse section (T.S.) or Longitudinal Section (L.S.) or Radial Longitudinal Section (R.L.S.) or Tangential Longitudinal Section (T.L.S.) and Powder microscopy which can help in evaluation of different constituents by using different staining reagents. Specimens were soaked in water or other sovents depending upon the hardness of the sample and transverse sections were taken using sharp razor blades. Few microscopic sections were cut by Microtome sectioning. Numerous temporary and permanent mounts of the microscopical sections of the specimen were made and examined microscopically. Different staining reagents were applied on transverse sections so as to differentiate between different cell wall components.

\section{PRELIMINARY}

PHYSIOCHEMICAL

SCREENING OF PLANT EXTRACTS [6-17]

Determination of Solvent Extractive Values

Determination of Water Soluble Extractive Value

$5 \mathrm{~g}$ of the air-dried drug, coarsely powdered were macerated with $100 \mathrm{ml}$ of water in closed flask for 24 hours, shaking frequently during the first 6 hours and allow standing for 18 hours. It was filtered rapidly taking precaution against loss of water, then the filtrate was evaporated $25 \mathrm{ml}$ of the filtrate to dryness in a tared flat-bottomed shallow dish, and dried at $105^{\circ} \mathrm{C}$ then weighed. The percentage of water-soluble extractive with reference to the air dried was calculated.

\section{Determination of Alcohol Soluble Extractive Value}

$5 \mathrm{gm}$ of the air dried and coarsely powdered drug was macerated with $100 \mathrm{ml}$ of ethanol of the specific strength in a closed flask for 24 hours, shaking frequently during the first 6 hours and allow standing for 18 hours. There after filter rapidly taking precaution against loss of ethanol. Evaporate $25 \mathrm{ml}$ of the filtrate to dryness in a tared flat bottomed shallow dish, dry at $105^{\circ} \mathrm{c}$ and weigh. The percentage of ethanol soluble extractive with reference to the air dried drug has to be calculated.

\section{Determination of Moisture Content}

Moisture is an inevitable component of crude drugs, which must be eliminated as far as practicable. Method of determination of moisture content include 
the loss on drying, the test for loss on drying determines both water and volatile matter in the crude drug. It can be carried out either by heating at $100^{\circ} \mathrm{C}-105^{\circ} \mathrm{C}$ or in a dessicator over phosphorous pentoxide under atmospheric or reduced pressure at room temperature for specific period of time.

\begin{abstract}
Ash Value
Ash value is helpful in determining the quality and purity of a crude drug, especially in the powdered form. On incineration, crude drugs normally leave an ash usually consisting of carbonates, phosphates and silicates of sodium, potassium, calcium and magnesium. The total ash of a crude drug reflects the care taken in its preparation. A higher limit of acid-insoluble ash is imposed, especially in case where silica may be present or when the calcium oxalate content of the drug is very high.
\end{abstract}

Total ash value
Weighed accurately about 2 to $3 \mathrm{~g}$ of the powdered drug in a tared silica crucible. Incinerated at a temperature not exceeding $450{ }^{\circ} \mathrm{C}$ for $4 \mathrm{hr}$, until free from carbon, cooled and weighed. The percentage of ash with reference to air-dried was calculated following formula.

$$
\% \text { Total ash value }=\quad \begin{aligned}
& \text { Wt. of total ash } \\
& \text { Wt. of crude drugs }
\end{aligned}
$$

\section{Water Soluble Ash Value}

Boiled the ash with $25 \mathrm{ml}$ of water. Filtered and collected the insoluble matter on an ash less filter paper, washed with hot water and ignited in a tared crucible at a temperature not exceeding $450{ }^{\circ} \mathrm{C}$ for $4 \mathrm{hr}$. Cooled in a desiccator and weighed. Substrate the weight of insoluble matter from the total weight of ash. The difference in weight represented weight of water soluble ash. Calculated the percentage of water soluble ash with reference to the air- dried drug by using the following formula.

\begin{abstract}
$\%$ Water soluble ash value $=$
\end{abstract}

\section{Wt. of total ash-Wt.of water insoluble ash $\times 100$}

Wt. of crude drug taken

\section{Acid Insoluble Ash Value}

Boiled the ash for $5 \mathrm{~min}$ with $25 \mathrm{ml}$ of $2 \mathrm{M}$

HCL. Filtered and collected the insoluble matter on an ash less filter paper, washed with hot water and ignited in a tared crucible at a temperature not exceeding $450^{\circ}$ $\mathrm{C}$ for $4 \mathrm{~h}$. cooled in a desiccator and weighed. Calculated the percentage of acid insoluble ash with reference to the air -dried drug was calculated by using following formula,

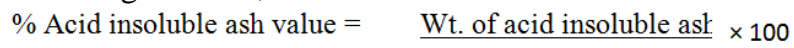

Wt. of crude drug taken

\section{Preliminary Qualitative Test}

The various extract of Andographis panniculata was subjected to preliminary qualitative phytochemical investigation. The various tests and reagent used are given below.

\section{ALKALOIDS}

Preparation of test solution: The test solution was prepared by dissolving extracts in the dilute hydrochloric acid.

Mayer' test: The acidic test solution with Mayer's reagent (Potassium Mercuric iodide) gave cream colored precipitate.

Hager's test: The acidic test solution with Hager's reagent (Saturated picric acid solution) gave yellow precipitate.
Dragendorff's test: The acidic solution with Dragendorff's reagent (Potassium bismuth iodide) showed reddish brown precipitate.

Wagner's test: The acidic test solution treated with Wagner's reagent (Iodine in potassium iodide) gave brown precipitate.

Tannic acid test: The acidic test solution treated with Tannic acid gave buff colour precipitate.

Picrolonic acid test: Alkaloids gave yellow colour precipitate with picrolonic acid.

\section{AMINO ACID}

Millon'test: To the test solution add about $2 \mathrm{ml}$ of millon's reagent white precipitate indicates presence of amino acid.

Ninhydrine test: To the test solution add Ninhydrine solution, boil, violet colour indicates presence of amino acid.

\section{CARBOHYDRATES}

Preparation of test solution: The test solution was prepared by dissolving the test extracts with water. Then it was hydrolyzed with 1 volume of $1 \mathrm{~N}-\mathrm{HCL}$ and subjected to following chemical test.

Molisch's test: Test solution with few drops of Molisch's reagent and $2 \mathrm{ml}$ of conc. $\mathrm{H}_{2} \mathrm{So}_{4}$ added slowly from the sides of the test tubes. It showed a purple ring at the junction of two liquids. 
Barfoed's test: $1 \mathrm{ml}$ of test solution is heated with $1 \mathrm{ml}$ of Barfoed, $s$ reagent on water bath, if red cupric oxide is formed, monosaccharide is present. Disaccharides on prolong heating (about $10 \mathrm{~min}$.) may also cause reduction, owing to partial hydrolysis to monosaccharide.

Benedict's test: Test solution treated with Benedict' reagent and after boiling on water bath, it showed reddish brown precipitate.

Fehling's test: The test solution when heated with equal volume of Fehling's A and B solution, gave orange red precipitate, indicating the presence of reducing sugars

Flavonoids: The flavonoids are all structurally derived from the parent substance called flavones. The flavonoids occur in the free from as well as bound to sugars as glycosides. For this reason, when analyzing flavonoids it is usually better to examine the flavonoids in hydrolyzed plant extracts.

Preparation of test solution: To a small amount of extract added equal volume of $2 \mathrm{M} \mathrm{HCL}$ and heated in a test tube for 30 to $40 \mathrm{~min}$ at $100^{\circ} \mathrm{C}$. The cooled extract was filtered, and extracted with ethyl acetate The ethyl acetate was concentrated to dryness, and used to test for flavonoids.

Shinoda test: Test solution with few fragments of magnesium ribbon and conc. HCL showed pink to magenta red colour. To a small quantity of test solution when lead acetate solution was added, it formed yellow colored precipitate.

Alkaline reagent test: Test solution when treated with sodium hydroxide solution showed increase in the intensity of yellow colour, which becomes colorless on addition of few drops of dilute acid.

\section{GLYCOSIDES}

Preparation of test solution: The test solution was prepared by dissolving extract in the alcohol or hydroalcoholic solution.

\section{TEST FOR CARDIAC GLYCOSIDES}

Kedde' test: Add one drop of $90 \%$ alcohol and 2 drops of $2 \% 3,5$ - dinitro benzoic acid in $90 \%$ alcohol. Make alkaline with $20 \%$ sodium hydroxide solution, purple colour is produced. The colour reaction with 3, 5dinitro benzoic acid depends on the presence of $\alpha, \beta$ unsaturated lactones in the aglycone.

Baljet's test: The test solution treated with sodium picrate gave yellow to orange colour.

Raymond's test: Test solution treated with hot methanolic alkali, violet colour is produced.
Bromine water test: Test solution dissolve in bromine water give yellow precipitate.

Keller-killani test for digitoxose: The test solution treated with few drops of Fecl3 solution and mixed, then $\mathrm{H}_{2} \mathrm{So}_{4}$ containing $\mathrm{Fecl} 3$ solution was added, it formed two layers. Lower layer reddish brown, upper layer turns bluish green.

Legal's test: Test solution when treated with pyridine (made alkaline by adding sodium nitroprusside solution) gave pink to red colour.

\section{Test for Anthraquinone glycosides \\ Borntrager's Test}

Boiled powdered drug with $5 \mathrm{ml}$ of $10 \%$ sulphuric acid for five minutes. Filtered while hot, cooled the filtrate shaken gently with equal volume of benzene. Benzene layer was separated and then treated with half of its volume solution ammonia (10\%). Allowed to separate it. The ammonical layer acquired rose pink colour due to presence of anthraquinones.

\section{Proteins}

Preparation of Test Solution: The test solution was prepared by dissolving the extract in water.

Millon's Test: Test solution was treated with millon's reagent and heated on a water bath. The proteins were stained red

Biuret test: Test solution was treated with $40 \%$ sodium hydroxide and dilute copper sulphate solution gave blue colour.

Xanthoproteic test: Test solution was treated with conc. $\mathrm{HNO}_{3}$ and boiled which gave yellow precipitate.

Modified Borntrager's test: C-glycosides of anthraquinones require more drastic conditions for hydrolysis. Hydrolysis of the drug was carried out with $5 \mathrm{ml}$ of dilute of HCL and $5 \mathrm{ml}$ of $5 \%$ solution of $\mathrm{Fecl}_{3}$. For hydrolyzed extract procedure was carried out as described under Borntrager's test.

\section{TEST FOR STEROIDS}

Preparation of test extract solution: The extract was refluxed separately with alcoholic solution of potassium hydroxide till complete saponification. The saponified extract was diluted with water and unsaponificable matter was extracted with diethyl ether. The ethereal extract was evaporated and the residue (saponificable matter) was subjected to the following test by dissolving the residue in the chloroform.

Salkowski test: To the test extract solution add few drops of conc. $\mathrm{H}_{2} \mathrm{SO}_{4}$ shaken and allowed to stand, lower layer turned red indicating the presence of steroids. 
Libermann - Burchard test: The test solution treated with few drops of acetic anhydride and mixed, when conc. $\mathrm{H}_{2} \mathrm{SO}_{4}$ was added from the sides of the test tubes, it showed a brown ring at the junction of the two layers and the upper layers turned green. Added few drops of concentrated $\mathrm{H}_{2} \mathrm{SO}_{4}$. Blue colour appeared.

Sulphur test: Sulphur test when added in to the test solution, it sank it.

Tannins and phenol compound: To 2-3 $\mathrm{ml}$ of alcoholic or aqueous extract, added few drops of following reagents.

5\% Fecl $_{3}$ solution: Deep blue- black colour.

Lead acetate solution: White precipitate.

Bromine water: Discoloration of bromine water

Acetic acid solution: Red colour solution.

Dilute iodine solution: Transient red colour.

One drop of $\mathrm{NH}_{4} \mathrm{OH}$, excess $10 \% \mathrm{AGNO}_{3}$ solution. Heated for $20 \mathrm{~min}$ in boiling water bath. White precipitate was observed, then dark silver mirror deposited on wall of test tube.

\section{TRITERPENOIDS}

Preparation of test extract solution: The test extract solution was prepared by dissolving extract in the chloroform.

Salkowski test: Few drops of concentrated sulphuric acid were added to the test solution, shaken and on standing lower layer turned golden yellow.

\section{TLC analysis for differentPhytochemicals}

T.L.C. plate coated with $0.25 \mathrm{~mm}$ layer of silica gel GF 254 with fluorescent indicator, (Mercks) were used. (Each plate dimension is $10 \mathrm{~cm}$ long and $2 \mathrm{~cm}$ width).
Activation of pre-coated Silica gel $\mathbf{G 6 0 F}_{\mathbf{2 5 4}}$

Dry in hot oven at $105^{\circ} \mathrm{C}$ for one to two hour.

Sample: Alcoholic Extract of test sample.

Solvent system: Toluene, Ethyl Acetate: Formic acid $[[5: 4: 1]$

Visualization: Iodine Vapor \& UV Short Wave Length.

\section{ReSUlT AND DiscuSsion}

Kalamegha is one of the ingredients of many important formulations like kwath, Varunadi Ghrit, Satviryadi Kwath, and many others, following observations were found. In Charaka Samhita, properties of Kiratatikta and Kalamegha drugs have been mentioned as best Jwarchikitsa, Stanyajanan, Kusht chikitsa (C.S.Su. 07/146) signifying the usage of drug in any sort of disorders because of having skin disorder pacifying activity. The collected drug were studied organoleptically with naked eye \& magnifying lens, with the help of different Organoleptic features i.e. Colour, Odour, Taste, and Appearance were recorded (Table-1). The microscopic characteristics study revealed the presence of parenchymatic cells, lignified fibres, nitrogenous compound, starch, scleroids \& trichome (Table-2). Various physiochemical parameters were studied and result was tabulated in the Table- 3 . The extractive value was found to be $10.76 \%$ (Alcohol Extractive Value) and $13.55 \%$ (Aqueous Extractive Value).The phytochemical screening (Table-4) revealed the presence of the carbohydrate, alkaloid, glycoside, saponin, flavonoids, tannins, Aminoacid \& protein. TLC fingerprinting showed 5 spots having $\mathrm{R}_{\mathrm{f}}$ values $0.10,0.20,0.42,0.78$ and 0.92 at $366 \mathrm{~nm}$. At $254 \mathrm{~nm}$ the sample showed 4 spots having $R_{\mathrm{f}}$ values $0.19,0.41$, 0.74 and 0.92 and at Visible Light: showed 3 spots having $R_{\mathrm{f}}$ values $0.20,0.51$ and 0.87 . TLC fingerprinting revealed the presence of phytoceuticals showed the therapeutic utility of the plant (Table-5).

Table-1: Macroscopy of Kalmegh

\begin{tabular}{|l|l|l|}
\hline Appearance & Andrographis panniculata & Organoleptic characters \\
\hline $\begin{array}{l}\text { General } \\
\text { appearance and } \\
\text { stem }\end{array}$ & $\begin{array}{l}\text { Acutely } 4 \text { angled, nodose, jointed and nearly glabrous, } \\
\text { branches cross armed, 4 sided, spreading or horizontal. }\end{array}$ \\
\hline
\end{tabular}




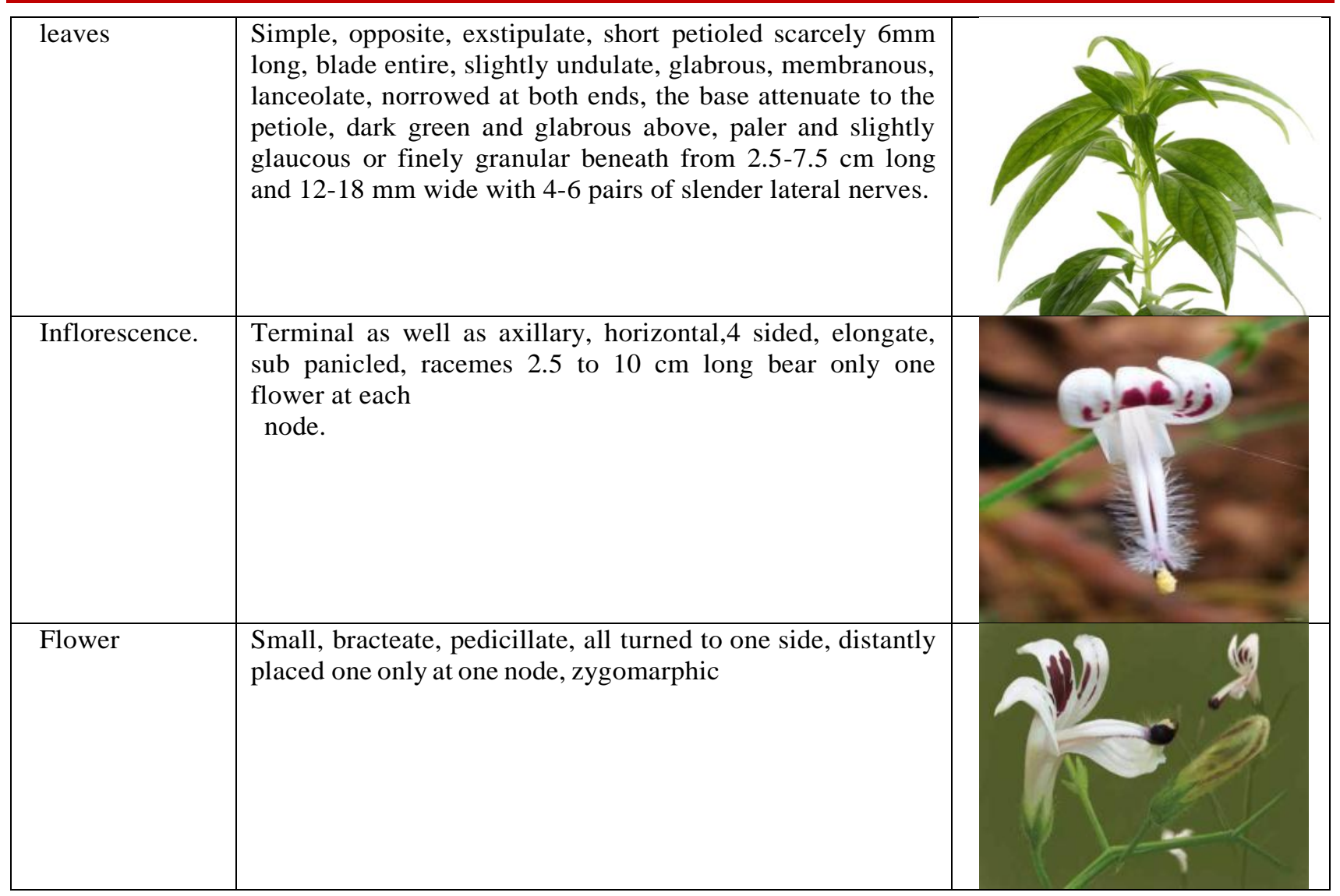

Table-2: Powder Microscopy

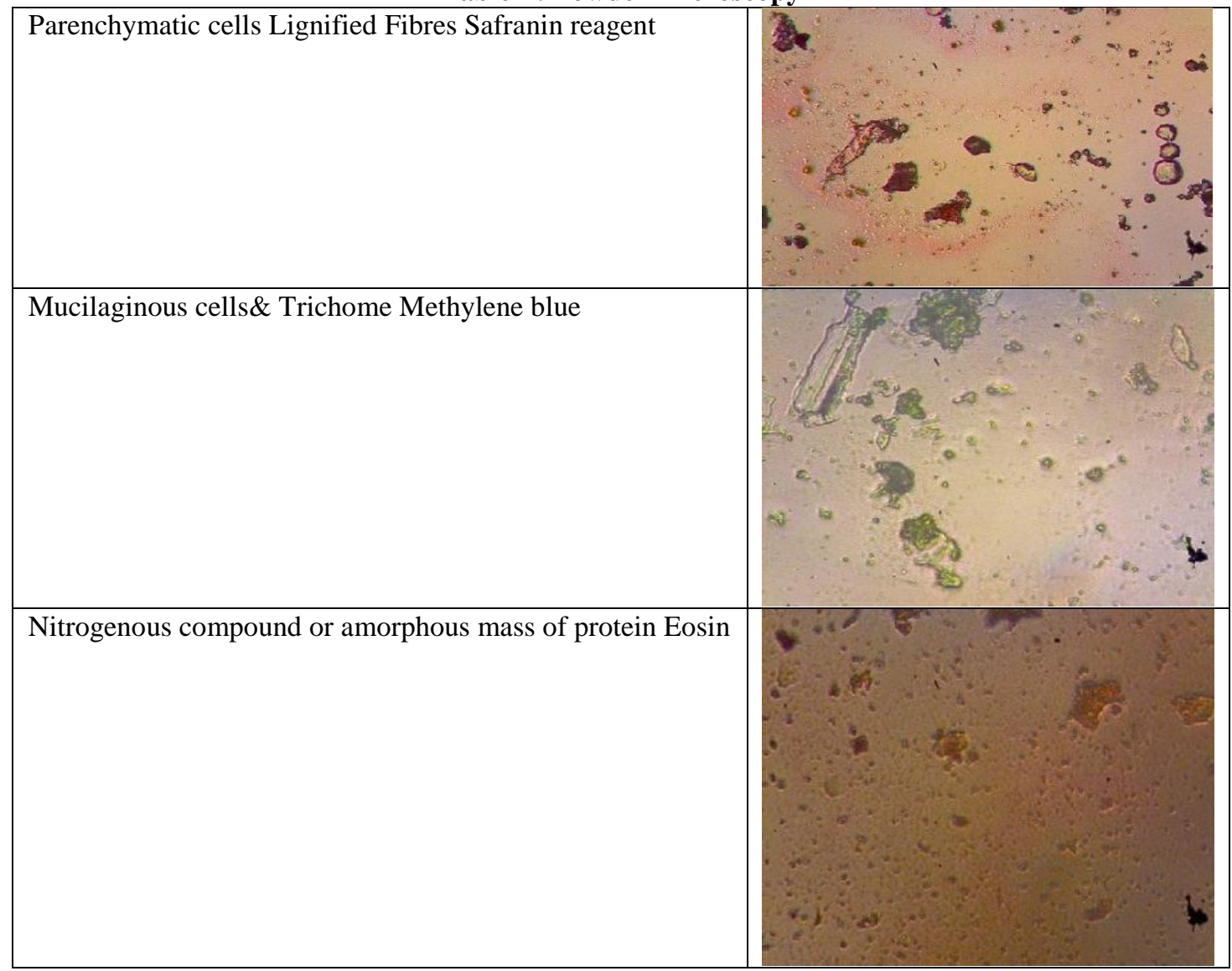




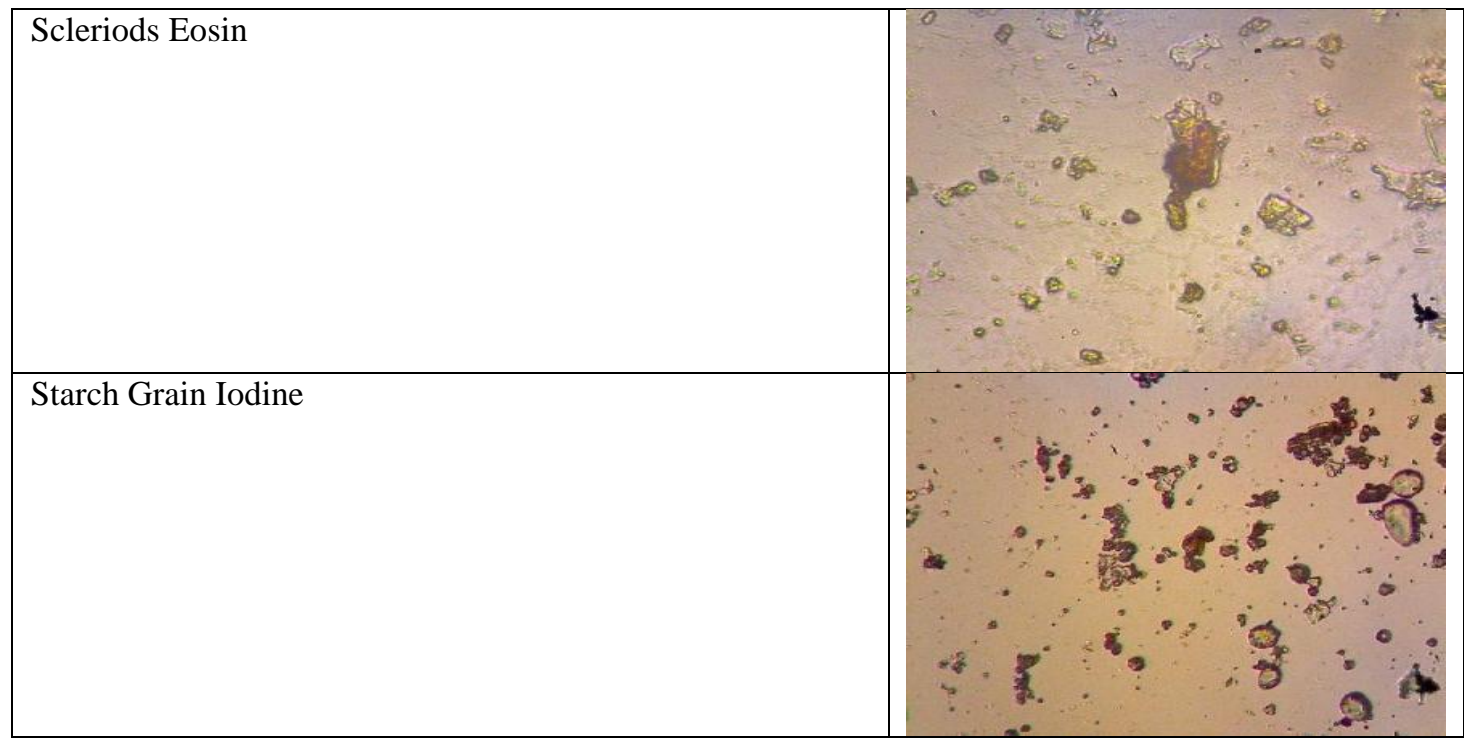

Table-3: Physiochemical study of Parameters

\begin{tabular}{|l|l|l|}
\hline S. No & \multicolumn{1}{|c|}{ Tests } & Andographis paniculata (S1) \\
\hline 1 & Moisture content & $8.70 \% \mathrm{w} / \mathrm{w}$ \\
\hline 2 & $\mathrm{pH}$ & 7.97 \\
\hline 3 & Alcohol Extractive Value & $10.76 \% \mathrm{w} / \mathrm{w}$ \\
\hline 4 & Aqueous Extractive Value & $13.55 \% \mathrm{w} / \mathrm{w}$ \\
\hline 5 & Foreign matter & $1.34 \% \mathrm{w} / \mathrm{w}$ \\
\hline 6 & Total Ash & $8.62 \% \mathrm{w} / \mathrm{w}$ \\
\hline 7 & Acid Insoluble Ash & $1.72 \% \mathrm{w} / \mathrm{w}$ \\
\hline 8 & Water Soluble Ash & $3.42 \% \mathrm{w} / \mathrm{w}$ \\
\hline
\end{tabular}

Table-4: Results of preliminary phytochemical analysis

\begin{tabular}{|c|c|c|c|c|}
\hline \multirow[t]{2}{*}{ Sr. No. } & \multirow[t]{2}{*}{ Name of the Test } & \multicolumn{2}{|c|}{ thes } & Observation \\
\hline & & Aqueous Extract & Alcoholic Extract & Pet.ether Extract \\
\hline $\mathbf{1}$ & $\begin{array}{ll}\text { Tests for sterols } \\
\text { 1. } & \text { Salkowski's Test } \\
\text { 2. } & \text { Libermann Burchard's Test }\end{array}$ & $\begin{array}{l}+ \\
+\end{array}$ & $\begin{array}{l}+ \\
+\end{array}$ & $\begin{array}{l}+ \\
+\end{array}$ \\
\hline 2 & $\begin{array}{ll}\text { Test for glycosides } \\
\text { 1. } & \text { Baljet's Test } \\
\text { 2. } & \text { Brontrager Test }\end{array}$ & $\begin{array}{l}+ \\
+\end{array}$ & $\begin{array}{l}- \\
-\end{array}$ & $\begin{array}{l}- \\
-\end{array}$ \\
\hline 3 & $\begin{array}{l}\text { Tests for saponins } \\
\text { 1. Foam Test }\end{array}$ & + & + & - \\
\hline 4 & $\begin{array}{c}\text { Test for carbohydrates } \\
\text { 1. Molish's Test } \\
\text { 2. Barfoed's Test } \\
\text { 3. Benedict's Test }\end{array}$ & $\begin{array}{l}+ \\
+ \\
+\end{array}$ & $\begin{array}{l}- \\
- \\
-\end{array}$ & $\begin{array}{l}- \\
- \\
-\end{array}$ \\
\hline 5 & $\begin{array}{ll}\text { Tests for alkaloids } \\
\text { 1. } \\
\text { 2. } \text { Mayer's Test. } \\
\text { 3. } \\
\text { Wagner's Test. } \\
\text { Dragendorff's Test }\end{array}$ & $\begin{array}{l}+ \\
+ \\
+\end{array}$ & $\begin{array}{l}+ \\
+ \\
+\end{array}$ & $\begin{array}{l}- \\
- \\
-\end{array}$ \\
\hline 6 & $\begin{array}{ll}\text { Tests for flavonoids } \\
\begin{aligned} & \text { 1. } \text { Ferric chloride Test. } \\
& \text { 2. } \text { Shinoda Test. } \\
& \text { 3. } \text { Alkaline Reagent Test. } \\
& \text { 4. } \text { Lead Acetate Test. } \\
&\end{aligned}\end{array}$ & $\begin{array}{l}+ \\
+ \\
+ \\
+\end{array}$ & $\begin{array}{l}+ \\
+ \\
+ \\
+\end{array}$ & $\begin{array}{l}+ \\
+ \\
+ \\
+\end{array}$ \\
\hline 7 & $\begin{array}{l}\text { Tests for tannins } \\
\text { 1. Ferric chloride Test. } \\
\text { 2. } \quad \text { Gelatin Test }\end{array}$ & $\begin{array}{l}- \\
-\end{array}$ & $\begin{array}{l}+ \\
+\end{array}$ & $\begin{array}{l}- \\
-\end{array}$ \\
\hline 8 & $\begin{array}{l}\text { Test for amino acid and protein } \\
\text { 1. Biurete test }\end{array}$ & + & - & - \\
\hline
\end{tabular}


Table-5: TLC Fingerprinting

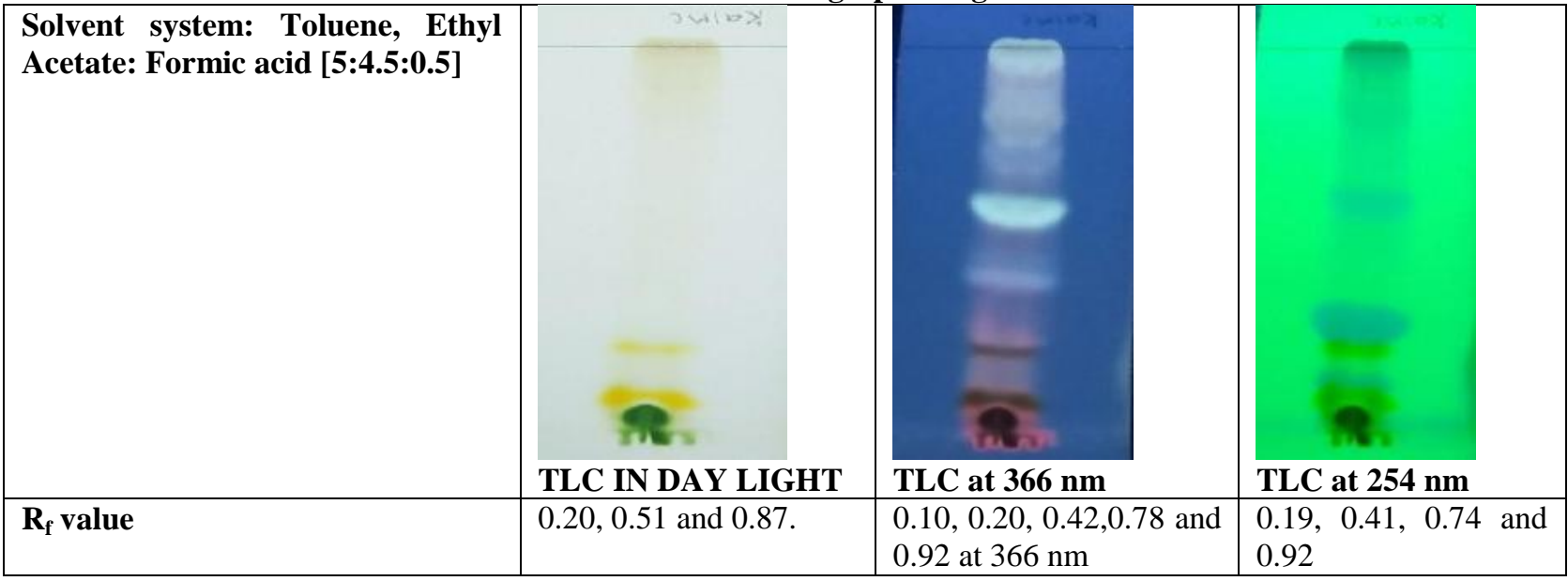

\section{CONCLUSION}

The present study deals with macroscopic, microscopic, phytochemical analysis and TLC fingerprinting. These studied will provide referentially information for correct identification and for standardization. This study also aid in the assessing of adulteration and substitution in market sample of the plant.

\section{REFERENCE}

1. Himesh S., \& Singhai, A. K. (2018). Evaluation of wound healing activity of methanolic extract of Annona squamosa leaves in hydrogel delivery system. American Journal Pharm Tech Res. 8(3):190-198.

2. Kumar, A., Dora, J., Singh, A., \& Tripathi, R. (2012). A review on king of bitter (Kalmegh). Int J Res Pharm Chem, 2(1), 116-124.

3. Mishra, S. K., Sangwan, N. S., \& Sangwan, R. S. (2007). Phcog Rev.: Plant Review Andrographis paniculata (Kalmegh): A Review. Pharmacognosy Reviews, 1(2), 283-298.

4. The Ayurvedic Pharmacopoeia of India, Part-I, Vol-8 Ministry of Health and Family Welfare, Government of India, New Delhi, Controller of Publication Civil Lines, 1st Edition, Print: 2011, 106.

5. Niranjan, A., Tewari, S. K., \& Lehri, A. (2010). Biological activities of Kalmegh (Andrographis paniculata) and its active principles: A Review. 1(2):125-135.

6. Mukharjee, P. K. (2002). Quality control of herbal drugs- an approach to evaluation of botanicals $31^{\text {st }}$ edition. New Delhi, Business Horizons Pharmaceuticals. Publications; 183-197.

7. Khandelwal, K. R. (1996). Practical Pharmacognosy. $\quad 3^{\text {rd }}$ edition. Pune: Nirali Prakashan. 165.
8. Semwal, P. (2019). Pharmacognostical \& TLC Fingerprinting of Kiratatikta. EAS Journal of Pharmacy and Pharmacology, 1(6), 170-177.

9. Kumar, A. (2019). Efficacy of Anti-Inflammatory Potential of Desmodium gangeticum Extracts, Advanced Research in Chemistry and Applied Science, 1(1):19-23.

10. Kumar, A., \& Kumar, D. (2019). Preliminary Pharmacognostical Standardization of Ipomoea turpethum, European Journal of Biomedical and Pharmaceutical sciences, 6(13):391-397.

11. Soni, S. (2019). Botanicals Used for AntiHyperlipidemic Activity: A Review. International journal of Pharmacy \& pharmaceutical Research, 15(3):25-37.

12. Jitender, K. M. (2017). Overview on: characteristic of isoflavones \& Its Biological Activity. International Journal of Biology, Pharmacy and Allied Science, 6(3):447-467.

13. Jitender, K. M. (2008). Evaluation of antiinflammatory activity of Gymnema sylvestre leaves extract in rats. International Journal of Green Pharmacy, 114-115.

14. Jitender, K. M. (2011). Evaluation of Anxiolytic activity of Boerhaavia Diffusa Hydro-Alcoholic extract of leaves in rats. International Research Journal of Pharmacy, 2(10):90-92.

15. Nautiyal, A. (2019). Preliminary Phytochemical Evalution and Antioxidant potential of Aerial parts of Desmodium gangeticum. Asian Journal of Medical and Health Research, 4(10):1-11.

16. Krishan, A., Kumar, D., \& Rawat, A. (2019). Efficacy of Anti-Inflammatory Potential of Desmodium gangeticum Extracts, Advanced Research in Chemistry and Applied Science, 1(1):19-23.

17. Kumar, A., Kumar, D., \& Rawat, A. (2019). Characterization of Flavonoids in Aqueous extract of Desmodium gangeticum by RP-HPLC. Global Academic Journal of Pharmacy and Drug Research, 1(1):1-4. 